\title{
NORMAS PARA A APRESENTAÇÃO DE ARTIGOS
}

A Revista Textos de Economia é uma publicação semestral do Departamento de Economia e Relações Internacionais da Universidade Federal de Santa Catarina que tem por objetivo oferecer um espaço à divulgação de artigos científicos de todas as filiações teóricas das ciências econômicas e das demais ciências sociais.

Os artigos remetidos à Revista Textos de Economia devem ser inéditos, podendo ser em língua portuguesa, espanhola ou inglesa. Os artigos não deverão ultrapassar 25 páginas em Times New Roman 12, espaço 1,5.

Cada artigo deverá ser acompanhado de resumo (máximo de 10 linhas), e palavras-chave (máximo de três), ambos em português e inglês, além da classificação JEL.

$\mathrm{O}(\mathrm{s})$ nome(s) do(s) autor(es), filiação institucional e endereço eletrônico e telefone para correspondência devem aparecer apenas na folha de rosto, evitando a identificação da autoria para os pareceristas. A avaliação também será feita através de pareceristas anônimos.

A submissão dos artigos é feita exclusivamente por meio eletrônico. Os artigos podem ser encaminhados para helton@cse.ufsc.br. Também podem ser submetidos através do portal dos periódicos da UFSC (www.periodicos.ufsc.br).

As notas de rodapé devem ser numeradas em ordem seqüencial.

As referências devem ser apenas aquelas citados no texto e devem ser apresentadas no final do texto, em ordem alfabética, conforme a NBR 6023 de 2002 da ABNT.

As tabelas e os gráficos devem ser numerados, acompanhados do título e da fonte. Os gráficos devem ser gerados no MS-Excel e vir acompanhados das respectivas tabelas.

Os artigos encaminhados à Revista Textos de Economia serão submetidos à apreciação, sendo os autores informados da aceitação ou da recusa de seus trabalhos. 

Endereço para correspondência:

Universidade Federal de Santa Catarina

Centro Sócio-Econômico

Departamento de Economia e Relações Internacionais

Revista Textos de Economia

Campus Universitário - Trindade

88040-900 - Florianópolis-SC

Fone: 0(XX) 4837219458 e 0(XX) 4837216508

E-mail: parienti@terra.com.br helton@cse.ufsc.br 


